\title{
Pengobatan alternatif penyakit tulang STUDI KasUS KEARIFAN LOKAL paRA TERAPIs PENYAKIT TUlaNg dI WILAYAH JaWA BaRAT
}

\author{
ALTERNATIVE MEDICINE FOR BONE DISEASE \\ CASE STUDY OF LOCAL WISDOM \\ OF BONE DISEASE THERAPISTS IN WEST JAVA
}

\author{
Mumuh Muhsin $Z^{1}$., Dade Mahzuni ${ }^{2}$, Ayu Septiani ${ }^{3}$ \\ Fakultas Ilmu Budaya, Universitas Padjadjaran \\ Jl. Raya Bandung-Sumedang Km. 21, Jatinangor, Sumedang \\ E-mail: mumuh.muhsin@unpad.ac.id ${ }^{1}$ dade.mahzuni@unpad.ac.id ${ }^{2}$ ayu.septiani@unpad.ac.id ${ }^{3}$
}

DOI: 10.30959/patanjala.v11i3.544

\begin{abstract}
Abstrak
Penelitian tentang pengobatan alternatif penyakit tulang ini dilakukan dengan tujuan, pertama, untuk mengungkap faktor-faktor yang menjadi alasan pengobatan alternatif penyakit tulang masih sangat diminati oleh masyarakat; kedua, menjelaskan kearifan lokal yang digunakan oleh para terapis penyakit tulang dalam praktik pengobatan. Penelitian ini menggunakan metode deskriptif-kualitatif yang bertujuan untuk mendeskripsikan kearifan lokal para terapis penyakit tulang di wilayah Jawa Barat. Pengumpulan datanya dilakukan melalui studi lapangan, wawancara, dan studi pustaka. Hasil yang diperoleh dari penelitian lapangan adalah terungkapnya alasan masyarakat masih menggunakan jasa pengobatan tradisional. Alasan itu meliputi alasan praktis, ekonomis, berdaya guna, dan berhasil guna. Selain itu, terungkap juga kearifan lokal yang diwujudkan dalam cara penanganan pasien. Simpulannya adalah pengobatan alternatif penyakit tulang bukan lagi sebagai alternatif tetapi menjadi pilihan utama dan pertama. Oleh karena itu, kearifan lokal yang berkait dengan hal itu perlu diwariskan kepada generasi berikutnya dan sekaligus disistematisasi secara metodologis.
\end{abstract}

Kata Kunci: pengobatan alternatif, penyakit tulang, kearifan lokal.

\section{Abstract}

This research aims to study why alternative medicine for bone disease is still in great demand by the public and to explain the local wisdom used by therapists for bone disease in West Java. This study uses a descriptive-qualitative method. Data collection is carried out through field studies, interviews, and literature studies. The results show that efficaciousness of its treatment are the reasons why the appeal for alternative medicine for bone disease aren't declining, besides it having practical and economic advantages. In addition, local wisdom in handling patients plays an important part in its success. The conclusion is that alternative treatments for bone disease are no longer an alternative but they are becoming the first and foremost choice. Therefore, its local wisdom needs to be passed on to the next generation and at the same time methodologically systematized.

Keywords: alternative medicine, bone disease, local wisdom. 


\section{A. PENDAHULUAN}

Pengobatan modern (Barat) masuk ke Indonesia diperkirakan pada abad ke-19 dan berkembang lebih intensif pada abad ke-20. Hal itu dilakukan oleh pemerintah kolonial terkait dengan kepentingan mereka akan kesehatan penduduk pribumi demi keberhasilan proyek ekonomi kolonial yang memerlukan sumber daya manusia yang sehat dan kuat (Direktorat Jenderal PP \& PL, Departemen Kesehatan RI, 2007: 4-5 dan 10-12). Pengobatan modern pada masa itu lebih terfokus pada jenis-jenis penyakit tertentu yang berkembang saat itu, yaitu cacar, pes, dan malaria. Akan tetetapi, pada saat itu dan pada saat-saat sebelumnya, penyakit yang berkembang di masyarakat tidak terbatas pada tiga jenis penyakit tersebut.

Terdapat jenis-jenis penyakit lain yang tidak tertangani oleh pengobatan modern. Artinya, masyarakat tradisional sudah memiliki sistem pengobatannya sendiri, yang oleh manusia sekarang dilabeli sebagai pengobatan alternatif. Hingga sekarang, praktik pengobatan tradisional, khususnya yang berkait dengan penyakit tulang, cukup populer di wilayah Jawa Barat. Bahkan dalam beberapa kasus, penyakit tulang yang tidak tertangani oleh pengobatan modern, bisa diatasi melalui pengobatan alternatif. Belakangan ini, bahkan, sering terjadi juga, kedua metode tersebut saling melengkapi satu sama lain.

Di Jawa Barat, mungkin juga di wilayah-wilayah lainnya, praktisi pengobatan alternatif penyakit tulang sangat banyak. Bisa jadi hampir di setiap wilayah kecamatan bisa ditemukan. Hal ini mengindikasikan banyak hal, di antaranya: jumlah penderita tulang cukup banyak, minat masyarakat menggunakan jasa terapis tradisional cukup tinggi, nilai daya guna dan hasil guna pun relatif tinggi.

Berdasarkan uraian di atas dapat dikemukakan perumusan masalah sebagai berikut:

1. Kondisi atau faktor-faktor apa yang menjadikan pengobatan tradisional, khususnya berkaitan dengan penyakit tulang, masih sangat diminati di wilayah Jawa Barat?

2. Bagaimana metode berbasis kearifan lokal yang digunakan oleh para terapis penyakit tulang dalam praktik pengobatannya?

Dengan mengacu pada rumusan masalah tersebut tujuan penelitian ini pun meliputi dua hal, yaitu:

1. Mengungkap faktor-faktor yang menjadi alasan pengobatan alternatif penyakit tulang masih sangat diminati oleh masyarakat;

2. Menjelaskan kearifan lokal yang digunakan oleh para terapis penyakit tulang dalam praktik pengobatan.

Studi terdahulu memperlihatkan adanya sejumlah tempat pengobatan tradisional para terapis penyakit tulang yang tersebar di Jawa Barat, di antaranya di Bandung, Cianjur, Bogor, Sukabumi, Garut, Tasikmalaya, Sumedang, Ciamis, dan Pangandaran. Dari tinjauan ilmu kesehatan dan ilmu antropologi, meskipun belum banyak, pengobatan tradisional penyakit tulang bukanlah suatu hal baru untuk dibahas, penelitian ini terinspirasi dari penelitian terdahulu yang dilakukan oleh Zakaria (2012 : 187-197). Penelitian ini mengkaji publikasi-publikasi yang diterbitkan pada masa lalu, khususnya masa kolonial, baik berupa buku, jurnal, majalah, surat kabar bisa menjadi akses untuk mengetahui dan merekonstruksi masa lalu kesehatan di Nusantara. Tujuan penelitian ini adalah menginventarisasi dan mengidentifikasi sejumlah publikasi yang terbit pada masa lalu dengan terlebih dahulu diuraikan konteks sejarahnya. Simpulannya adalah ketersediaan sumber bibliografis mengenai sejarah kesehatan di Indonesia yang cukup banyak itu dapat digunakan untuk merekonstruksi kondisi kesehatan di Indonesia masa kolonial. Pengetahuan sejarah kesehatan ini sangat berguna untuk melihat perubahan, kesinambungan, paralelisme, dan perbandingan masalah kesehatan di berbagai tempat pada berbagai periode. 
Karya terdahulu yang banyak dijadikan rujukan untuk tulisan ini adalah skripsi yang ditulis oleh Ida Rahmadewi (2009) berjudul "Pengobatan Tradisional Patah Tulang Guru Singa". Dari skripsi Antropologi Fakultas Ilmu Sosial Ilmu Politik Universitas Indonesia tersebut banyak diperoleh sumber acuan untuk kepentingan penulisan artikel ini.

Karya lainnya adalah penelitian yang dilakukan oleh Muhastiningsih (1990: 4748). Dalam penelitiannya mengenai peran serta dukun patah tulang dalam program upaya kesehatan tradisional di Desa Cimande, Kecamatan Caringin Bogor, diungkapkan bahwa lima belas (100\%) terapis/tukang urut ${ }^{1}$ patah tulang berjenis kelamin laki-laki. Tiga orang di antaranya $(20,01 \%)$ berusia $35-44$ tahun, lima orang $(33,33 \%)$ berusia antata 45-54 tahun, dan tujuh orang $(46,67 \%)$ berusia lebih dari 55 tahun. Tiga belas orang bekerja sebagai petani dan dua orang berdagang. Tiga orang berpengalaman 3-5 tahun menjadi terapis patah tulang, tiga orang berpengalaman 6-10 tahun, dan sembilan orang berpengalaman lebih dari 10 tahun.

Pada umumnya penyedia layanan ini mengaku belum pernah mendapatkan pelatihan khusus untuk memberikan pengobatan tulang ini. Rata-rata metode yang digunakan adalah pembebatan tulang yang patah/sakit dengan kain yang diolesi minyak tertentu. Ada pula yang 'mengobati' bagian yang trauma dengan cara menarik bagian tulang. Tindakan yang dilakukan biasanya tergantung dari jenis trauma tulang yang dialami pasien.

Menurut Notosiswoyo (1995: 131132) dalam hasil penelitiannya mengenai pengobatan tradisional penyakit tulang Cimande, pengobatan tradisional masih diminati oleh masyarakat, di antaranya

\footnotetext{
${ }^{1}$ Biasanya, seseorang menghindarkan diri dari sebutan dukun karena sering berkonotasi negatif, kata yang lebih netral adalah terapis atau tukang urut. Dukun biasanya ada pelibatan kekuatan supranatural. Terapis atau tukang urut lebih tradisional.
}

adalah karena faktor-faktor sosial, budaya, ekonomi, psikologis, dan alasan kepraktisan.

Karya selanjutnya yang membahas mengenai pengobatan tradisional (alternatif) adalah artikel yang ditulis oleh Lis Nurrani, Supratman Tabba dan Hendra S. Mokodompit (2015). Dalam artikel tersebut penulis mengkaji pemanfaatan tumbuhan obat yang dilakukan oleh masyarakat pada zona tradisional TNAL. Dari hasil penelitiannya, teridentifikasi sebanyak 78 jenis tumbuhan yang digunakan oleh masyarakat dalam pengobatan tradisional di mana sebagian besar merupakan famili fabaceae. Habitus tumbuhan mayoritas berupa pohon (42\%) dan bagian tumbuhan yang paling banyak dimanfaatkan yaitu daun sebanyak $40 \%$. Umumnya tumbuhan digunakan untuk pengobatan luar seperti alergi dan luka ringan (29 jenis); peningkat stamina tubuh (17 jenis); serta penyakit dalam dan kronis (32 jenis). Analisis fitokimia menunjukkan bahwa ekstrak kulit alstonia scholaris, batang homalium grandiflorum, daun crotalaria retusa, batang arcangelsia flava, dan batang tali togutil mengandung senyawa triterpenoid (anti malaria). Ekstrak kulit toyom (sterculia obongifolia) mengandung tanin, yang berfungsi menghentikan pendarahan dan menyembuhkan infeksi luka bakar.

Selanjutnya adalah artikel yang ditulis oleh Fadhila (2015: 50-57). Artikel tersebut mengkaji bahwa pengobatan patah tulang tradisional merupakan pengobatan yang telah lama dikenal oleh masyarakat dunia. Sekitar $80 \%$ penduduk dunia masih memilih untuk datang pada dukun patah saat mengalami patah tulang. Berdasarkan telaah beberapa literature, disebutkan bahwa salah satu alasan pasien memilih pengobatan patah tulang adalah biaya yang murah, namun tidak pernah disebutkan secara jelas berapa biaya yang harus dikeluarkan seorang pasien saat memutuskan untuk melakukan pengobatan pada dukun patah. Penelitian ini bertujuan untuk mengidentifikasi biaya pengobatan 
pada metode pengobatan patah tulang tradisional di Kabupaten Bireuen. Penelitian ini menggunakan metode kualitatif, yang berlangsung sejak Juni hingga Oktober 2014. Penelitian dilakukan di 7 tempat pengobatan patah tulang terhadap 28 orang pasien patah tulang. Hasil penelitian menunjukkan bahwa biaya yang harus dikeluarkan oleh seorang pasien yang menjalani rawat inap adalah antara Rp 2.500.000 - Rp 11.000.000, bergantung pada tingkat keparahan fraktur yang dialami pasien. Jika seorang pasien ingin melakukan pengobatan rawat jalan, maka biaya yang harus dikeluarkannya adalah Rp 800.000 - Rp 5.000.000.

Dalam penelitian ini terdapat enam konsep yang digunakan dan perlu dijelaskan terlebih dahulu, yaitu penyakit, sistem medis, pengobatan alternatif, sistem pengobatan, sistem pengobatan penyakit tulang, dan kearifan lokal. Penyakit menurut Kamus Besar Bahasa Indonesia (2014: 1205) yaitu gangguan kesehatan yang disebabkan oleh bakteri, virus, atau kelainan sistem faal atau jaringan pada organ tubuh (makhluk hidup). Dalam penelitian ini patah tulang termasuk satu di antara jenis penyakit tulang. Berdasarkan pengertian tersebut maka tulang adalah jaringan ikat yang terdiri dari sel, serat, dan matriks ekstraseluler. Dengan demikian, ketika ada gangguan tulang maka itu disebut sebagai penyakit.

Ada berbagai macam penyakit tulang, namun yang menjadi objek pengobatan utama para terapis adalah kasus fraktur atau patah tulang, yang biasanya disertai dengan cedera di jaringan-jaringan sekitarnya. Terdapat beberapa jenis fraktur, yaitu :

1. Patah tulang tertutup, yaitu tulang yang patah tidak nampak dari luar.

2. Patah tulang terbuka majemuk, yaitu tulang yang patah tampak dari luar karena tulang menembus kulit yang mengalami robekan. Patah tulang seperti ini rentan terinfeksi.

3. Patah tulang kompresi, yaitu akibat dari tenaga yang menggerakkan sebuah tulang melawan tulang lainnya, atau tenaga yang menekan melawan panjangnya tulang. Kondisi ini sering terjadi pada wanita lanjut usia yang tulang belakangnya menjadi rapuh karena osteoporosis.

4. Patah tulang karena tergilas, yaitu terjadi karena tenaga yang sangat kuat yang menyebabkan retakan sehingga terjadi tulang pecah. Jika darah ke bagian tulang yang terkena mengalami gangguan, maka penyembuhannya akan berjalan sangat lambat.

5. Patah tulang avulse, yaitu disebabkan oleh kontraksi otot yang kuat, sehingga menarik bagian tulang tempat tendon otot tersebut melekat. Hal ini paling sering terjadi pada tungkai dan tumit.

6. Patah tulang patologis, yaitu jika sebuah tumor/kanker telah tumbuh ke dalam tulang dan menyebabkan tulang menjadi rapuh.

Sistem medis adalah suatu unsur yang ada pada setiap kebudayaan. Sistem medis menurut Dunn (dalam Foster dan Anderson, 1986: 41) adalah pola-pola dari pranata sosial dan tradisi budaya yang menyangkut perilaku yang disengaja untuk meningkatkan kesehatan, meskipun hasil dari tingkah laku khusus tersebut belum tentu berupa kesehatan yang baik. Saunders (dalam Foster dan Anderson, 1986: 44) juga menyatakan bahwa sistem medis merupakan suatu kompleksitas yang luas dari pengetahuan, kepercayaan, teknik, peran, norma-norma, nilai-nilai, ideologi, sikap, adat istiadat, upacara, dan lambang, yang saling berkaitan dan membentuk suatu sistem yang saling menguatkan dan saling membantu.

Secara umum, sistem medis dapat dibagi ke dalam setidaknya dua kategori besar, yaitu sistem teori penyakit dan sistem perawatan kesehatan. Sistem teori penyakit meliputi kepercayaankepercayaan mengenai ciri sehat, sebabsebab sakit, serta pengobatan dan teknik- 
teknik penyembuhan lain yang digunakan oleh para dokter. Sebaliknya, suatu sistem perawatan kesehatan memperhatikan caracara yang dilakukan masyarakat untuk merawat orang sakit dan untuk memanfaatkan pengetahuan tentang penyakit untuk menolong pasien.

Penyembuhan terhadap suatu penyakit di dalam sebuah masyarakat dilakukan dengan cara-cara yang berlaku di dalam masyarakat atau sesuai dengan kepercayaan masyarakat tersebut. Ketika manusia menghadapi masalah dalam hidup, termasuk sakit, maka ia secara alamiah akan mencari obat bagi penyembuhan penyakitnya (Hastuti, 2006:1). Bukan hanya pengalaman, faktor sosial budaya, dan faktor ekonomi yang mendorong seseorang mencari pengobatan, melainkan juga organisasi sistem pelayanan kesehatan, baik modern maupun tradisional, sangat menentukan dan berpengaruh terhadap perilaku mencari pengobatan (Lumenta, 1989: 87-88).

Pengobatan alternatif dapat dikatakan sebagai cara penyembuhan yang diselenggarakan dengan cara di luar ilmu kedokteran dan atau ilmu keperawatan yang menggunakan cara, alat, atau bahan yang tidak termasuk dalam standar pengobatan modern, dan digunakan sebagai alternatif atau pelengkap pengobatan kedokteran modern tersebut. Berbagai istilah telah digunakan untuk cara pengobatan yang berkembang di tengah masyarakat. WHO (1974) menyebutnya sebagai traditional medicine atau pengobatan tradisional. Para ilmuwan sendiri lebih menyukai traditional healing. Ada pula yang menyebut metode ini sebagai folk medicine, alternative medicine, ethno medicine, atau indigenous medicine (Agous dan Jacob, 1992: 59)

Hingga sekarang, praktik pengobatan tradisional, khususnya yang berkait dengan penyakit tulang, cukup populer di wilayah Jawa Barat. Bahkan dalam beberapa kasus, penyakit tulang yang tidak tertangani oleh pengobatan modern, bisa diatasi melalui pengobatan alternatif. Sering terjadi juga, kedua metode tersebut saling melengkapi satu sama lain. Para terapis (patah) tulang merupakan agen profesional dari pengobatan tradisional yang masih cukup banyak dijadikan alternatif oleh pasien penyakit tulang, terhadap cara pengobatan yang diberikan oleh ilmu kedokteran (Mangunsudirdjo, 1992: 76).

Foster dan Anderson (1986) menyatakan bahwa pemilihan pengobatan alternatif biasanya dipengaruhi oleh tingkat pendidikan masyarakat yang masih rendah serta kurangnya informasi tentang kesehatan. Namun demikian, Kasnodiharjo (2005) menegaskan bahwa nilai-nilai tradisional saat ini tidak hanya dianut warga pedesaan tetapi juga masyarakat perkotaan.

Secara umum, sistem pengobatan dapat dibagi dalam dua golongan besar, yaitu sistem medis ilmiah yang merupakan hasil perkembangan ilmu pengetahuan (terutama dalam dunia Barat) dan sistem medis tradisional yang hidup dengan aneka warna kebudayaan manusia (Kalangie, 1976: 15). Pengobatan modern adalah pengobatan yang dilakukan secara ilmiah (Samsunjaya, 2007: 1). Pengobatan tradisional merupakan suatu sistem pengobatan berdasarkan pada pengalaman dan keterampilan turun-temurun (Handoko, 2008: xxxii). Pengobatan tradisional inilah yang dimaksud sebagai pengobatan alternatif, di luar pengobatan medis.

Menurut Undang-Undang RI No. 23 tahun 1992 tentang kesehatan, pengobatan tradisional diartikan sebagai salah satu upaya pengobatan dan atau perawatan cara lain di luar ilmu kedokteran dan atau ilmu keperawatan, mencakup cara (metode), obat, dan pengobatannya, yang mengacu pada pengetahuan dan keterampilan yang turun temurun, baik yang asli maupun yang berasal dari luar Indonesia, dan diterapkan sesuai dengan norma yang berlaku dalam masyarakat. Kondisi bangsa Indonesia yang terdiri dari ribuan pulau dan beragam suku bangsa serta tersedianya flora dan fauna yang demikian 
kaya juga menjadi faktor pemicu berkembangnya pengobatan tradisional. Hal lain yang juga menjadi pendorong maraknya pengobatan tradisional sebagai alternatif ini adalah kesadaran masyarakat untuk kembali ke alam (back to nature) (Nafisah, 2000: 335-336 dalam Lestari, 2004: 2).

Berbagai jenis dan cara pengobatan alternatif terdapat dan dikenal dalam masyarakat Indonesia, sesuai dengan keanekaragamannya (Agoes, 1992: 61), yaitu:

1. Pengobatan tradisional dengan ramuan obat. Misalnya, pengobatan dengan ramuan asli Indonesia, pengobatan dengan ramuan obat Cina, pengobatan dengan ramuan obat India

2. Pengobatan spiritual/kebatinan. pengobatan atas tradisional kepercayaan/keyakinan Misalnya, dasar pengobatan atas dasar agama, pengobatan dengan dasar getaran magnetis

3. Pengobatan tradisional dengan memakai peralatan/perangsangan. Misalnya, akupuntur, yaitu pengobatan atas dasar ilmu pengobatan Cina yang menggunakan penusukan jarum dan penghangatan moxa (daun Arthemesia vulgaris yang dikeringkan), pengobatan tradisional urut pijat, pengobatan tradisional patah tulang, pengobatan tradisional dengan peralatan (tajam/keras), pengobatan tradisional dengan benda tumpul.

4. Pengobatan tradisional yang telah mendapat pengarahan dan pengaturan pemerintah. Misalnya, persalinan oleh dukun beranak, pengobatan oleh tukang gigi tradisional.

Dalam Sistem Pengobatan

Penyakit Tulang, para dukun atau terapis penyakit tulang pada umumnya melakukan pengobatan dengan cara mengurut untuk mereposisi tulang atau otot yang mengalami patah atau terkilir, dan memfiksasi. Reposisi dilakukan dengan splak atau bidai atau kayu dan memberi kompres dengan ramuan dan akar-akaran. Pada umumnya, pasien meminta bantuan medis pada tahap awal kejadian atau setelah berobat dengan pengobatan modern.

Dalam satu atau dua dekade belakangan ini masalah kearifan budaya lokal atau, sering disingkat menjadi kearifan lokal, sangat banyak diperbincangkan. Perbincangan tentang kearifan budaya sering dikaitkan dengan masyarakat lokal. Dalam literatur asing, kearifan lokal sering dikonsepsikan sebagai kebijakan setempat (local wisdom), pengetahuan setempat (local knowledge), atau kecerdasan setempat (local genious). Kearifan lokal diartikan sebagai pandangan hidup dan pengetahuan serta sebagai strategi kehidupan yang berwujud aktivitas yang dilakukan oleh masyarakat lokal dalam memenuhi kebutuhan mereka (Alfian, 2013: 428). Senada dengan Alfian, Wibowo dan Gunawan (2015:17) berpandangan bahwa kearifan lokal adalah identitas atau kepribadian budaya sebuah bangsa yang menyebabkan bangsa tersebut mampu menyerap, bahkan mengolah kebudayaan yang berasal dari luar/bangsa lain menjadi watak dan kemampuan sendiri. Kearifan lokal adalah pandangan, sikap, dan kemampuan suatu komunitas di dalam mengelola lingkungan, yang memberikan kepada komunitas itu daya tahan dan daya tumbuh di dalam wilayah di mana komunitas itu berada. Dengan kata lain, kearifan lokal merupakan jawaban kreatif terhadap situasi geografis, politis, historis, dan situasi-situasi lain yang bersifat lokal.

Hal tersebut pun senada dengan pendapat Geertz sebagaimana dikutip oleh Kuper (1999: 98) yang mengatakan kebudayaan adalah suatu sistem makna dan simbol yang disusun di mana individuindividu mendefinisikan dunianya, menyatakan perasaannya, dan memberikan 
penilaian-penilaiannya; suatu pola makna yang ditransmisikan secara historik diwujudkan di dalam bentuk-bentuk simbolik melalui sarana di mana orangorang mengkomunikasikan, mengabadikan, dan mengembangkan pengetahuan dan sikap-sikapnya ke arah kehidupan; suatu kumpulan peralatan simbolik untuk mengatur perilaku, sumber informasi yang ekstrasomatik. Berkaitan dengan pengobatan alternatif penyakit tulang, pengetahuan tentang metode pengobatan dan ramuan-ramuan obat berupa minyak, ramuan dari tumbuhtumbuhan yang diperoleh para terapis merupakan sarana yang dikomunikasikan, diabadikan, dan dikembangkan oleh para terapis di mana pengetahuan tersebut mereka peroleh secara turun-temurun dari orang tuanya yang dikomunikasikan secara lisan, melalui contoh, dan praktik.

\section{B. METODE PENELITIAN}

Penelitian ini menggunakan metode deskriptif-kualitatif yang bertujuan untuk mendeskripsikan latar belakang dari kearifan lokal para terapis penyakit tulang di wilayah Jawa Barat, seperti penggunaan minyak kelapa dengan syarat-syarat khusus dalam proses pembuatannya. Selain itu penggunaan daun-daun herbal yang diracik khusus dan diperoleh di hutan-hutan tertentu. Hal-hal seperti itu merupakan unsur-unsur lama yang masih digunakan hingga sekarang. Untuk mencapai sasaran yang diharapkan dan untuk menunjang kelancaran penelitian dilakukan langkahlangkah kegiatan berikut:

1. Persiapan lapangan, meliputi tahap: pengurusan surat izin penelitian, studi kepustakaan, dan penyusunan instrumen penelitian.

2. Pelaksanaan lapangan, berupa pengumpulan data di lokasi penelitian.

Penelitian dilakukan di beberapa tempat wilayah Jawa Barat, yaitu di Bandung dan Sukabumi. Dari masingmasing kabupaten tersebut diambil satu atau dua tempat di mana para terapis itu berdomisili dan melakukan praktik pengobatannya.

Jumlah informan yang diwawancarai tidak ditentukan sebelumnya, tetapi disesuaikan dengan kebutuhan dan kecukupan data penelitian serta dengan memperhatikan keterbatasan tenaga, waktu, dan biaya yang ada. Infroman yang dipilih tentu saja yang memiliki pengetahuan terkait dengan penelitian yang dikaji. Informan menjadi sumber data primer seperti terapis atau tukang urut dan pasien yang menggunakan jasa terapis/tukang urut untuk mengobati penyakit tulang mereka. Pemilihan informan ini berdasarkan pendapat Spradley (1997: 59-60) yang mengidentifikasikan lima persyaratan minimal untuk memilih informan dengan baik, yaitu bahwa informan yang baik adalah informan yang terenkulturasi penuh dengan kebudayaannya; terlibat secara langsung dalam peristiwa kebudayaan yang diteliti; mengetahui secara detail mengenai suasana kebudayaan yang tidak dikenal peneliti; mempunyai cukup waktu untuk berpartisipasi dalam penelitian; informan yang selalu menggunakan bahasa mereka untuk menggambarkan berbagai kejadian dan tindakan dengan cara yang hampir tanpa analisis mengenai arti atau signifikansi dari kejadian dan tindakan itu. Terapis tulang dan pasiennya memilki lima kriteria minimal yang dikemukakan oleh Spradley.

Adapun data mengenai kondisi umum wilayah atau lokasi penelitian dan permasalahan yang dihadapi penduduk pada umumnya diperoleh dari tokoh-tokoh formal serta tokoh non-formal, baik dari internal maupun eksternal wilayah penelitian. Untuk melengkapi data umum tersebut digunakan juga data sekunder berupa dokumen atau laporan tertulis yang diperoleh dari instansi terkait.

Teknik pengumpulan data dilakukan melalui tiga cara, yaitu pengamatan, wawancara mendalam, dan pengumpulan dokumen. Pengamatan (observation) 
dilakukan terhadap lingkungan fisik dan sosial. Kondisi fisik yang diamati meliputi lokasi pelayanan pengobatan para terapis penyakit tulang, metode pengobatan, obat, dan hasil pengobatannya. Selain itu, pengamatan juga digunakan untuk mengontrol jawaban-jawaban informan dan juga melengkapi informasi yang diperoleh dalam wawancara.

Pengumpulan data dengan menggunakan wawancara mendalam (indepth interview)merupakan pengumpulan data utama dalam penelitian ini. Melalui wawancara mendalam, informasi mengenai pengetahuan, keterampilan, dan pengalaman para terapis, dapat digali lebih mendalam dan rinci serta data mengenai keterkaitan antara satu aspek dengan aspek lainnya dalam suatu masalah dapat diperoleh secara lebih lengkap. Dengan cara demikian (pendalaman) dapat diperoleh data yang lebih utuh dan menyeluruh mengenai suatu aspek. Wawancara difokuskan kepada individu dengan melihat pedoman wawancara yang sudah dibuat sebelumnya.

Wawancara pertama-tama dilakukan terhadap para terapis penyakit tulang. Hal ini dilakukan karena peneliti memerlukan informasi awal di dalam memahami motivasi, pengalaman, dan keterampilan yang bersangkutan sebagai penyedia layanan kesehatan. Wawancara terhadap tokoh-tokoh tersebut dilakukan dengan mendatangi mereka di tempat pelayanan. Wawancara selanjutnya dilakukan terhadap pasien-pasien sebagai informan kunci. Pada awal wawancara, peneliti terlebih dahulu menyampaikan maksud dan tujuan wawancara. Hal ini penting agar informan dapat mengetahui maksud dan tujuan wawancara sehingga dapat tercipta suasana terbuka. Selanjutnya, peneliti menyodorkan beberapa pertanyaan dimulai dari masalah yang sederhana seperti keadaan keluarga, pekerjaan, dan masalah yang terkait dengan topik penelitian, yaitu penyakit tulang yang diderita serta hasil pengobatan yang dirasakan responden. Selama wawancara berlangsung, peneliti lebih banyak mendengarkan dan mencatat apa-apa yang disampaikan oleh informan agar informasi yang disampaikan tidak terputus.

Barulah apabila informan berhenti berbicara atau berbicara ke luar dari fokus permasalahan, sesekali peneliti melanjutkan pembicaraan dengan mengajukan pertanyaan-pertanyaan selanjutnya sesuai dengan topik yang didiskusikan. Pertanyaan-pertanyaan yang diajukan tidak terbatas pada pedoman wawancara tetapi juga dikembangkan dari jawaban-jawaban informan maupun kondisi yang berlangsung pada saat wawancara dilakukan. Setelah wawancara selesai, peneliti menanyakan kepada informan mengenai pasien-pasien lain sesuai dengan kriteria yang sudah ditentukan, yang dijadikan calon informan berikutnya. Selanjutnya ditentukan satu orang informan yang dikunjungi dan diwawancarai. Proses penentuan informan dan wawancara seperti tersebut dilakukan hingga informan terakhir diperoleh dan diwawancarai.

Selain data yang diperoleh dari pengamatan dan wawancara mendalam, juga dikumpulkan data sekunder melalui dokumentasi. Data sekunder tersebut meliputi data umum mengenai keadaan lokasi pengobatan, sarana dan prasarana pengobatan, dan lain-lain. Data sekunder tersebut berupa data kualitatif atau pun kuantitatif. Data sekunder (berupa dokumen) tersebut dapat berupa laporan hasil penelitian, laporan tahunan dinas atau instansi, profil desa atau kecamatan, serta dokumen-dokumen lainnya yang berkaitan dengan masalah penelitian. Untuk memperoleh dokumen tersebut, peneliti mendatangi langsung dinas atau instansi yang bersangkutan untuk menyalin, memfotokopi, atau memperolehnya melalui pihak dan media lain. 


\section{HASIL DAN BAHASAN \\ 1. Gambaran Umum Wilayah dan Masyarakat Jawa Barat}

Wilayah Jawa Barat merupakan wilayah yang dikenal dengan kawasan pegunungan. Wilayah ini juga dikenal sebagai wilayah yang subur dan sejuk sehingga selalu menjadi satu di antara tujuan wisata favorit di Indonesia. Di masa lalu, ada beberapa wilayah yang dijadikan sebagai tempat plesiran bagi orang-orang Eropa satu di antaranya adalah Bandung. Bandung sebagai tujuan wisata orangorang Eropa terutama pada akhir abad ke19 dan awal abad ke-20 menjadikan wilayah ini dikenal sehingga pembangunan fasilitas umum seperti kereta api dan hotel berkembang dengan pesat. Semakin banyaknya orang-orang Eropa yang datang menjadikan Bandung terkenal dengan wisata mode dan kulinernya sehingga dijuluki Parijs van Java.

Oleh karena wilayahnya yang sejuk ini maka secara tidak langsung memengaruhi karakter masyarakatnya. Masyarakat Jawa Barat dikenal sebagai orang yang ramah, lemah lembut, dan santun. Dalam melakukan aktivitas seharihari, masyarakat Jawa Barat banyak memanfaatkan alam. Di masa lalu, masyarakat Jawa Barat terbiasa hidup dengan memanfaatkan tumbuh-tumbuhan, batu-batuan, yang sudah tersedia di alam dekat dengan tempat tinggal mereka. Sebagai contoh dapat kita lihat pemanfaatan batuan yang disusun sebagai tempat peribadatan yang hingga kini masih dilestarikan yaitu Situs Astana Gede Kawali yang terletak di Ciamis, Jawa Barat. Potret kehidupan sehari-hari masyarakat Jawa Barat yang hingga kini juga dapat kita lihat adalah dari masyarakat adat yang sampai sekarang masih eksis. Sebut saja Masyarakat Baduy di Banten, Masyarakat Kampung Ciptagelar di Sukabumi, Masyarakat Kampung Naga di Tasikmalaya, Masyarakat Kampung Pulo di Garut, Masyarakat Kampung Kuta di Ciamis, Masyarakat Kampung Urug di
Bogor, dan Masyarakat Kampung Cireundeu di Cimahi.

Pada umumnya, masyarakat adat tersebut masih memegang teguh ajaranajaran leluhur untuk mencintai alam sekitar. Mereka diajarkan untuk memanfaatkan apa yang disediakan oleh alam untuk digunakan dalam memenuhi kebutuhan mereka sehari-hari. Namun demikian, ternyata tidak hanya masyarakat adat saja yang hingga kini masih mempertahankan ajaran leluhur untuk memanfaatkan alam, melainkan juga masyarakat umum yang tinggal di wilayah kota dan cenderung sudah mengalami kemajuan teknologi. Mereka adalah para terapis yang melakukan praktik untuk mengobati penyakit tulang. Dalam tulisan ini mereka berasal dari Bandung dan Sukabumi.

Salah satu lokasi pengobatan penyakit tulang di Bandung ada di Ujungberung. Kecamatan Ujungberung merupakan salah satu bagian Wilayah Timur Kota Bandung dengan memiliki luas lahan 661,276 Ha. Secara administratif Kecamatan Ujungberung dibatasi oleh :

- Bagian selatan: Kecamatan Cinambo Kota Bandung.

- Bagian utara: Kecamatan Cilengkrang Kabupaten Bandung.

- Bagian timur: Kecamatan Cibiru Kota Bandung.

- Bagian barat: Kecamatan Mandalajati Kota Bandung.

Secara geografis Kecamatan Ujungberung memiliki bentuk wilayah datar/berombak sebesar 35\% dari total keseluruhan luas wilayah. Ditinjau dari sudut ketinggian tanah, Kecamatan Ujungberung berada pada ketinggian 668 $\mathrm{m}$ di atas permukaan laut. Suhu maksimum dan minimum di Kecamatan Ujungberung berkisar 19-24 $\mathrm{C}^{\circ}$, sedangkan dilihat dari curah hujan berkisar $2.400 \mathrm{~mm} / \mathrm{th}$ dan jumlah hari dengan curah hujan yang terbanyak sebesar 45 hari. Kecamatan Ujungberung memiliki populasi jumlah 
penduduk 71.212 jiwa dan dibagi dalam 5 kelurahan yaitu: Pasir Endah, Cigending, Pasirwangi, Pasirjati, dan Pasanggrahan (Sumber: Kantor Kecamatan Ujungberung).

Sementara itu, wilayah di Sukabumi yang menjadi lokasi penelitian adalah Desa Semplak yang merupakan salah satu desa di Kecamatan Sukalarang. Kecamatan Sukalarang memiliki batas-batas wilayah yaitu di sebelah utara berbatasan dengan Kecamatan Sukaraja; di sebelah timur berbatasan dengan Kabupaten Cianjur; di sebelah barat berbatasan dengan Kecamatan Sukaraja; di sebelah selatan berbatasan denganKecamatan Cireunghas (Sumber: Kabupaten Sukabumi Dalam Angka 2012).

Pemanfaatan alam yang mereka lakukan berupa pemanfaatan tanamantanaman obat yang mereka temukan di hutan-hutan yang ada di Jawa Barat seperti Hutan di Gunung Sancang dan Gunung Manglayang. Mereka menggunakan tanaman-tanaman tersebut untuk mengobati beragam penyakit tulang yang diderita oleh pasien sebagai akibat dari kecelakaan, virus, bakteri, atau karena adanya riwayat penyakit seperti diabetes. Pengetahuan yang diperoleh tentang tumbuhan-tumbuhan tersebut dari pengalaman yang dialami oleh mereka sendiri dan dari ajaran orang tua.

Uraian tentang metode pengobatan, bagaimana memperoleh pengetahuan tentang pengobatan alternatif penyakit tulang, dan bagaimana regenerasi yang dilakukan terapis akan dijelaskan dalam subbab di bawah ini.

\section{Terapis Tulang di Jawa Barat}

Di Jawa Barat terdapat banyak tempat pengobatan penyakit tulang. Salah satu yang cukup menonjol di Kota Bandung (Ujungberung) adalah Bengkel Patah Tulang Mande. Sesungguhnya, nama "mande" atau "cimande" mengacu ke sebuah tempat di Bogor. Cimande adalah sebuah desa yang ada di Kecamatan Caringin, Kabupaten Bogor, Jawa Barat.
Kata "cimande" merupakan kependekan dari frase "cai iman anu hade" (arti harfiahnya, air iman yang baik) atau "ciri manusa anu hade" (ciri manusia yang baik).

Pada awalnya, Cimande erat kaitan dengan aliran pencak silat. Dalam perkembang selanjutnya, bukan hanya pencak silat, tetapi juga pengobatan atau penyembuhan terhadap luka atau sakit tulang akibat dari latihan pencak silat, bertarung antarpemain silat, atau perkelahian pada umumnya. Penyakit yang muncul akibat dari kegiatan itu adalah patah tulang, persendian terkilir, tulang retak, luka, memar, dan sebagainya.

Pada kenyataannya yang menderita penyakit semacam itu bukan hanya akibat dari perkelahian atau pertarungan tetapi bisa menimpa siapa pun akibat dari kecelakaan. Oleh karena itu, praktik pengobatannya pun meluas.

Di Bandung, baik Mande maupun Cimande, kedua nama tersebut digunanakan sebagai label praktik pengobatan karena terapisnya pernah belajar pengobatan tulang di sana dan dia mengabadikannya sebagai tempat praktik pengobatan tulang yang dikelolanya. Pertama, Bengkel Patah Tulang Mande, berlokasi di Jl. Vijaya Kusuma XV RT 07 RW 07 Pasirendah Ujungberung Kota Bandung.

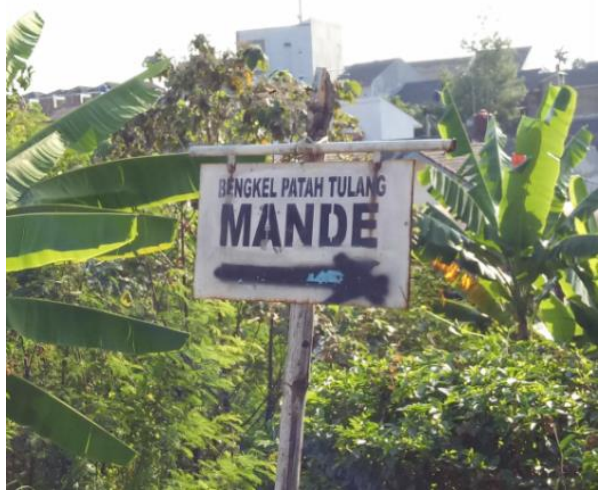

Gambar 1. Petunjuk Bengkel Patah Tulang Mande

Sumber: Dokumentasi Tim Peneliti. 
Pemimpin sekaligus pemilik bengkel tulang ini adalah Bapak H. Hasbi. Pak Hasbi lahir di Bandung, tepatnya Ujungberung pada 1 juli 1965. Bengkel ini tidak hanya memberikan pelayanan kepada pasien yang menderita patah tulang, namun melayani juga pengobatan untuk pasien penderita kanker tulang dan virus tulang. Bengkel Patah Tulang Mande sudah menangani banyak pasien dari berbagai daerah, bahkan dari luar negeri. Bukan hanya dari masyarakat biasa tetapi dari kalangan artis, atlet, dan pejabat dengan berbagai kasus mulai dari ringan sampai berat seperti banyak pasien yang sudah divonis harus diamputasi tetetapi lewat tangan atau keahlian Pak Hasbi pasien tersebut bisa sembuh total dan tidak diamputasi.

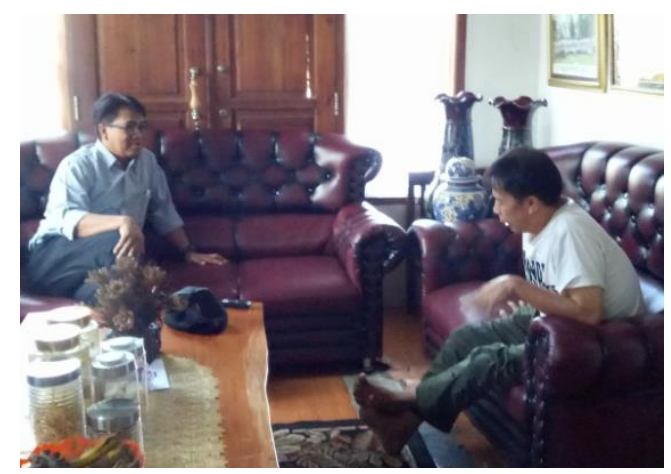

Gambar 2. Wawancara Peneliti dengan Pak Hasbi

Sumber: Dokumentasi Tim Peneliti.

Pengetahuan tentang pengobatan terhadap penyakit tulang tersebut diperoleh Pak Hasbi berdasarkan pengalaman pribadinya. Melalui wawancara yang dilakukan oleh penulis, Pak Hasbi menuturkan bagaimana awal mula dia memeroleh keahlian dalam pengobatan penyakit tulang. Pada suatu waktu sekitar tahun 1982, Pak Hasbi yang hobi jalanjalan dan hiking melakukan perjalanan ke Gunung Manglayang. Tujuannya ke sana hanya sekadar rekreasi. Kemudian, tanpa sengaja, Pak Hasbi mendengar suara tangisan seseorang dari sebuah rumah panggung. Didorong oleh rasa penasaran ia memberanikan diri mendekati rumah tersebut, ternyata di dalamnya ada seorang bapak yang sedang sakit parah karena patah tulang, sementara keluarganya menangis karena tidak tahu apa yang harus dikerjakan. Ketika dilihat oleh Pak Hasbi, luka di kakinya yang membengkak, sudah bernanah dan berulat. Saat itulah Pak Hasbi mengajukan dirinya untuk membantunya. Ia bersihkan lukanya dengan hati-hati dan penuh kasih sayang sampai lukanya bersih dari nanah dan ulat. Berhari-hari ia membantu Pak Tua itu, sampai kemudian ia melihat, dari lukanya tumbuh daging baru yang makin lama makin melebar sehingga lukanya semakin kecil. Dari situ Pak Hasbi mendapatkan pelajaran tentang pertumbuhan daging baru di atas luka yang ada. Sampai akhirnya Pak Tua tadi sembuh secara total. Pak Hasbi sangat senang sekali dengan usahanya menyembuhkan bapak tersebut. Sebagai rasa terimakasihnya kepada Pak Hasbi, Bapak yang disembuhkan tadi menganggapnya sebagai anak sendiri. Kalau Pak Hasbi sedang mencari tumbuhtumbuhan obat di hutan, maka si Bapak tadi dan keluarganya selalu membantunya dan memberikan makanan dan minuman.

Pengalaman lainnya adalah ketika anaknya mengalami musibah yaitu tergilas mobil truk. Sebagian tubuhnya remuk. Pada mulanya dari tempat kejadian, anaknya langsung dibawa ke rumah sakit, tetapi kemudian anaknya ia bawa ke rumah. Pada mulanya pihak rumah sakit keberatan, tetapi kemudian pihak rumah sakit mengizinkannya. Selama enam bulan anaknya diobati oleh ayahnya, dan akhirnya sembuh. Lalu anaknya dibawa ke pantai di daerah Sancang untuk dimandikan. Alasannya, air laut di wilayah itu sangat bersih dan baik untuk membersihkan bekas-bekas luka di tubuh anaknya.

Berdasarkan peristiwa tersebut kemudian keahlian Pak Hasbi yang dapat mengobati penyakit tersebar dari mulut ke mulut. Sampai akhirnya banyak orang yang sakit di sekitar wilayahnya 
mendatanginya untuk meminta bantuan penyembuhan. Pada mulanya Pak Hasbi merasa kebingungan bagaimana caranya mengobati banyak orang sakit yang datang ke rumahnya. Yang datang bukan hanya sakit tulang saja, tetapi berbagai macam penyakit, bahkan ada yang menderita gangguan jiwa. Dalam menghadapi pasienpasien tersebut, Pak Hasbi menggunakan tanaman-tanaman obat yang dia temukan di hutan. Sampai akhirnya dia memutuskan untuk mengobati penyakit tulang saja yang masih dilakukannya hingga sekarang.

Berdasarkan pengalaman yang dimiliki Pak Hasbi dalam mengobati penyakit tulang, ada beberapa faktor yang menjadi penyebab penyakit tulang yaitu virus, efek benturan, infeksi, penyakit gula, hepatitis, dan sebagainya. Sehingga dalam menangani pasien pun berbeda-beda. Biasanya, riwayat penyakit sebelumnya juga menjadi salah satu pertimbangan dalam melakukan pengobatan. Misalnya seorang pasien mempunyai penyakit herpes, maka lukanya tidak boleh dibalut karena akan membusuk, begitupan kalau memiliki penyakit gula, maka lukanya tidak boleh dibalut terlalu kencang. Selain itu, Pak Hasbi juga melihat karakter pasien. Apakah mudah emosi, mudah merasa pusing, atau bahkan pasien adalah orang sabar. Di balik semua itu, apa pun karakter pasiennya, Pak Hasbi tetap harus memperlihatkan akhlak penerimaan yang baik. Hal itu yang selalu diajarkan oleh orang tuanya untuk selalu sabar dan berbudi baik kepada siapapun apalagi tamunya.

Metode pengobatan secara umum yang dilakukan oleh Pak Hasbi meliputi pijit, leles (bahasa Sunda, pijitan yang lebih halus), dan reposisi tulang. Agar proses penyembuhan pasien bisa berlangsung cepat, saat pengobatan, Pak Hasbi selalu menyertakan ramuan obat yang berasal dari tumbuh-tumbuhan. Tumbuh-tumbuhan yang diracik untuk ramuan pengobatan, tidak hanya berasal dari Jawa Barat. Tumbuh-tumbuhan itu antara lain juga diperoleh dari Kalimantan,
Sumbawa, dan Papua. Terdapat jenis tumbuhan tertentu yang berkhasiat untuk menyambungkan dan membantu mempercepat pertumbuhan daging dan tulang. Saat memijit atau ngaleles, Pak Hasbi menggunakan minyak yang tidak hanya berfungsi sebagai pelumas tetapi juga mengandung obat. Minyak yang digunakan adalah minyak yang dibuat dan diracik di Desa Cimande, Bogor. Minyak ini sangat spesial karena dibuat dengan cara dan ritual tertentu.

Meskipun Pak Hasbi sudah memiliki rancangan pengobatan untuk pasien, dalam proses penyembuhan terhadap para pasiennya, seringkali $\mathrm{Pa}$ Hasbi menghadapi pasien yang tidak sabar, misalnya ingin cepat sembuh, ingin dibuka balutan lukanya, dan sebagainya. Padahal menurutnya, sudah ada aturan dalam pengobatannya, misalnya luka si pasien harus dibuka dan diperbaiki sepuluh hari sekali. Untuk tujuan itu, ia harus sabar meyakinkan pasien untuk mengikuti aturan atau ketentuan yang harus diikutinya agar kesembuhannya sempurna.

Pasien yang datang ke bengkel tulang Pak Hasbi sangat beragam dan dari berbagai kalangan, termasuk dari segi usia. Dalam menangani pasien-pasiennya tersebut ada perbedaan pelayanan berdasarkan usia, apakah si pasien masih muda umurnya ataukah sudah tua. Bahkan ia pernah menangani pasien yang berumur 125 tahun. Tetapi menurutnya, pertumbuhan tulang pasien tidak tergantung dari umur pasien itu sendiri. Yang penting, dalam proses penyembuhan si pasien harus sabar dan mengikuti aturanaturan yang berlaku. Misalnya mengenai pantangan, daging ayam yang dalam keadaan normal sangat baik untuk kesehatan tubuh, tetapi ketika sedang sakit (tulang), ayam daging kurang baik, karena jika dilanggar, maka lukanya akan menimbulkan bau dan akan lebih lama untuk disembuhkannya. Jadi pasien harus menghindari makanan-makanan yang berprotein tinggi. Begitu juga makanan atau minuman yang terlalu manis, dan juga 
makanan yang mengandung gas tinggi semuanya harus dihindari.

Pengobatan Bengkel Patah Tulang Mande dikenal tidak hanya di dalam negeri tetapi juga luar negeri. Pasien patah tulang dari Australia, Belanda, dan Perancis pernah juga datang berobat.

Tempat pengobatan patah tulang yang lainnya di Kota Bandung adalah Bengkel Tulang Aa Cimande, beralamat di Jl. A.H Nasution No.282 Cipadung, Kota Bandung. Bengkel tulang ini milik $\mathrm{H}$. Achmad Taupik atau yang dikenal dengan sebutan Aa Cimande.

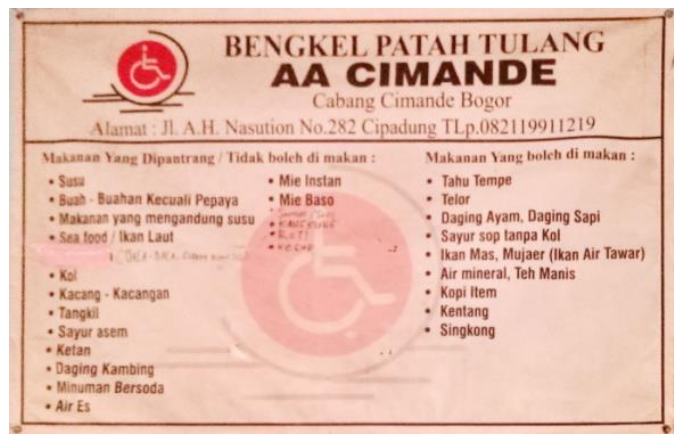

Gambar 3. Informai Bengkel Patah Tulang Aa Cimande

Sumber: Dokumentasi Tim Peneliti.

Metode dan hal lain yang berkaitan dengan praktik pengobatannya, bahkan minyak yang dipakai, yang dilakukan oleh Aa Cimande hampir mirip dengan yang dilakukan oleh Pak Hasbi. Kemiripan ini bisa dipahami karena kedua praktisi ini bersumber dari "ilmu atau guru" yang sama yaitu Cimande, Bogor. Bukan hanya itu, kedua praktisi ini pun secara geneologis ternyata punya hubungan kakak-adik.Pak Hasbi adalah kakaknya Pak Achmad Taupik.

Info awal tentang pengobatan alternatif penyakti tulang yang dilakukan oleh kedua praktisi ini bisa didapatkan secara mudah melalui media online. Selain kedua terapis tersebut, di Kota Bandung tentu saja terdapat cukup banyak terapis lainnya.

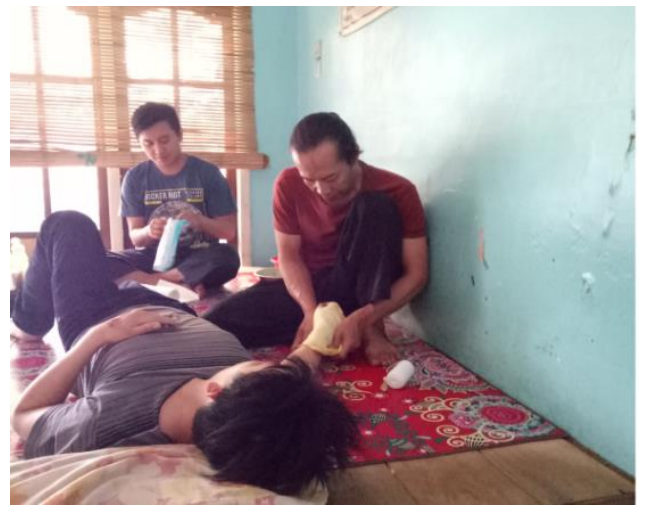

Gambar 4. Aa Cimande menangani pasien Sumber: Dokumentasi Tim Peneliti.

Di Kabupaten Bandung pun terdapat tempat pengobatan tradisional untuk penyakit tulang yaitu di Desa Citapen, Kecamatan Cililin, Kabupaten Bandung.Di desa ini terdapat puluhan ahli patah tulang dan urut otot. Beberapa nama terapis yang ada di desa ini antara lain: Abah Abun, Embah Suparjo, Achmad Saefudin, dan Obay. Untuk menunjang pengobatan, para ahli tulang tersebut menggunakan juga pengobatan atau alat medis modern, di antaranya obat antibiotik dan bantuan rontgen. Selain di Citapen, terdapat juga di daerah lainnya, yaitu di Desa Cikoneng, Ciparay dan di Desa Cikuya, Cicalengka. Di hampir setiap kabupaten/kota di Jawa Barat terdapat ahli pengobatan tradisional penyakit tulang.

Banyaknya praktik pengobatan tradisional penyakit tulang di beberapa tempat di Jawa Barat mengisyaratkan banyaknya pasien yang datang menggunakan jasanya. Yang jadi pertanyaan adalah faktor-faktor apa yang menyebabkan pengobatan tradisional penyakit tulang ini banyak diminati. Bisa dikatakan bahwa alasannya adalah karena faktor sosial, budaya, ekonomi, psikologis, dan alasan kepraktisan. Faktor-faktor tersebut tidak bisa secara tegas dipisahkan karena saling berkaitan.

Orang yang pernah punya pengalaman berobat secara langsung ke pengobatan tradisional penyakit tulang atau pernah mendengar dari pasiennya, dan pasien berhasil disembuhkan, secara sosial 
akan menyebarluaskan pengalamannya dan pengetahuan tersebut ke orang lain. Informasi dari mulut ke mulut bisa mendorong orang yang berpenyakit serupa untuk datang dan berobat ke terapis tradisional itu.

Secara budaya, bagi masyarakat Indonesia umumnya dan masyarakat Sunda khususnya, terapi tradisional penyakit tulang bukan fenomena baru tetapi sudah membudaya dari generasi ke generasi.Oleh karena itu, bila seseorang punya masalah dengan tulang, yang pertama dituju adalah para terapis tulang itu.

Secara ekonomi pun, berobat ke terapis tulang tradisional hampir dipastikan jauh lebih murah dibandingkan dengan datang ke dokter ahli tulang atau pun rumah sakit khusus tulang. Sebagai imbalan atas jasa pengobatan, para terapis itu seringkali tidak memasang tarif tetapi serelanya pasien saja. Atau, kalaupun ada angka nominal rupiah yang dihitung, itu dikenakan pada pasien inap, untuk sewa tempat dan makan. Atau juga untuk mengganti bahan/alat yang digunakan seperti perban, kayu, obat/ramuan.Itu pun tidak mahal jika dibandingkan dengan datang berobat ke dokter atau rumah sakit.

Secara psikologis, ada orang yang karena sudah turun-temurun selalu datang ke terapis tradisional jika punya masalah dengan tulang, berkecenderungan untuk selalu datang ke terapis itu. Bahkan secara fanatis selalu datang ke terapis yang sama.

Selain itu, ada juga karena alasan praktis. Dapat dikatakan praktis karena lokasi tempat terapis dekat dengan tempat pasien berdomisili, jalur transportasi untuk menjangkaunya mudah, tidak ada syarat atau prosedur administratif yang rumit. Atas dasar alasan-alasan tersebut, para penderita penyakit tulang memiliki kecenderungan untuk menggunakan jasa pengobatan tradisional.

Pada umumnya, pengetahuan para terapis tulang diperoleh secara turuntemurun. Artinya, pengetahuan tersebut diwarisi dari orang tuanya. Hal yang agak menarik adalah pengetahuan dan keterampilan tersebut jarang diturunkan atau diajarkan ke orang lain yang tidak ada hubungan darah sama sekali.

Meskipun pengetahuan tersebut bersifat turun-temurun, tetapi tetap ada proses belajar (proses sosialisasi). Proses belajarnya melalui melihat dan membantu saat orang tuanya menangani pasien, menirukan, mempraktikkan, dan seterusnya. Dengan demikian, sesungguhnya tidak perlu ada kekhawatiran dalam hal regenerasi.

Untuk Bengkel Tulang Mande misalnya, dia mempunyai beberapa asisten yang umumnya adalah kerabatnya. Asisten ini nantinya bisa meneruskan praktik pelayanan jasa pengobatan penyakit tulang secara mandiri. Begitu juga dengan Haji Asep, terapis penyakit tulang dari Desa Cisemplak Sukabumi, anaknya sudah mulai mengasisteni bapaknya.

Meskipun ada unsur-unsur spiritualnya, praktik pengobatan tradisional pada umumnya bersifat logis dan rasional. Tampaknya mereka cukup menguasai anatomi tubuh manusia. Pak Hasbi, terapis di Bengkel Tulang Mande misalnya, punya pengetahuan tentang jenis-jenis dedaunan yang berkhasiat untuk "menyambung atau merekatkan" tulang atau "menumbuhkan" daging. Dedaunan atau benda lainnya dijadikan ramuan dalam bentuk minyak atau cairan. Minyak atau cairan itu dioleskan, digosokkan, atau dipijitkan ke bagian yang sakit dari si pasien. Tidak tampak ada doa-doa khusus yang dibacakan.

Berbeda dengan Haji Asep, dalam pengobatannya, Haji Asep hampir tidak menggunakan media ramuan apa pun. Hanya saja sebelum melakukan pengobatan, Haji Asep ber-tawassul dan berdoa terlebih dahulu dan ditiupkan pada sebotol air. Kemudian sebagian dari air yang sudah didoakan itu diminum oleh pasien. Selanjutnya pasien diterapi dengan cara dipijit atau dibetulkan tulangnya. Berdasarkan keterangan dari Pak Hasbi dan Haji Asep, mereka sering bekerja sama dengan dokter atau rumah sakit tulang. 


\section{Model Pewarisan Keahlian Pengobatan Alternatif Penyakit Tulang}

Suatu pengetahuan atau keahlian khusus yang memiliki manfaat praktis bagi kehidupan masyarakat tentu saja perlu dilestarikan. Termasuk keahlian dalam melakukan pengobatan alternatif sebagaimana yang dilakukan oleh Pak Hasbi (Aa Mande), Aa Cimande, dan Haji Asep.

Model pewarisan keahlian dalam pengobatan alternatif yang dilakukan oleh Pak Hasbi, Aa Cimande, dan Haji Asep dalam mewariskan keterampilannya melakukan pengobatan alternatif penyakit tulang sesuai dengan konsep yang dikemukakan oleh Cavalli-Sforza dan Feldman (dalam Kusmaya, 2014). Menurut Cavalli-Sforza dan Feldman, terdapat tiga model pewarisan yaitu pewarisan tegak (vertical transmission), pewarisan miring (diagonal transmissions), dan pewarisan mendatar (horizontal transmissions). Model pewarisan tegak yaitu pewarisan berlangsung melalui mekanisme genetik yang diturunkan secara lintas generasi. Model pewarisan miring yaitu pewarisan berlangsung melalui orang dewasa lain yang tidak memiliki ikatan genealogis seperti lembaga pendidikan formal, informal, dan nonformal. Model pewarisan mendatar yaitu pewarisan berlangsung melalui teman-teman sebaya dalam lingkungan dimana seseorang berkembang sejak lahir sampai dewasa (Septiani, 2018: 43-44). Berdasarkan pengamatan penulis, model pewarisan yang dilakukan oleh ketiga terapis tersebut adalah model pewarisan tegak atau vertical transmission. Hal tersebut dilihat dari pengetahuan tentang yang dimiliki oleh ketiga terapis tersebut disampaikan hanya kepada keponakan-keponakan mereka atau kerabat dekat mereka yang kemudian menjadi asisten-asisten mereka.

Namun demikian, tidak menutup kemungkinan bahwa pewarisan keahlian dalam melakukan pengobatan alternatif penyakit tulang dilakukan melalui model pewarisan miring dan mendatar. Hal tersebut tersirat dari pernyataan Pak Hasbi yang memiliki keinginan untuk dapat menyebarkan ilmu pengobatan penyakit tulang kepada orang lain di luar keluarga dan kerabatnya. Selain itu, pengembangan dan pelestarian ilmu pengobatan penyakit tulang ini juga ingin disebarkan dalam bentuk formal atau nonformal dengan membangun sekolah pengobatan penyakit tulang.

Pernyataan Pak Hasbi tersebut jika ditelaah lebih jauh menyiratkan bahwa ada keinginan besar dalam dirinya untuk menyebarluaskan pengetahuan tentang pengobatan alternatif penyakit tulang kepada khalayak sehingga terapis yang dibutuhkan juga lebih banyak. Oleh karena itu, kemungkinan terjadinya pewarisan kepada orang-orang di luar keluarga dan kerabat dekat sangat besar.

Dalam rangka mewujudkan cita-cita tersebut, Pak Hasbi mengajarkan keponakan-keponakannya. Dilihat dari segi manfaat praktis, mengajarkan kerabat sendiri cenderung lebih mudah karena sudah kenal sehingga dalam mengomunikasikannya pun lebih mudah.

Selain ingin membangun sekolah pengobatan alternatif penyakit tulang, Pak Hasbi pun ingin mempunyai tanah yang luas untuk membudidayakan tanamantanaman tertentu yang berkhasiat untuk pengobatan penyakit tulang. Sementara ini, untuk pengadaan bahan obat dari tumbuhtumbuhan, Pak Hasbi mencarinya ke hutan-hutan sambil berburu hewan yang jadi hama bagi petani. Salah satu hutan yang sering didatangi adalah Leuweung Sancang di Garut selatan.

Dalam proses pewarisan tentu saja terdapat proses belajar. Sebagaimana pendapat Cavalli-Spoza dan Fieldman yang dikutip oleh dalam Kusmaya (2014), menyatakan bahwa Cultural transmission can perpetuate its behavioral features among subsequent generations employing teaching and learning mechanisms. Berdasarkan kalimat tersebut penulis menyimpulkan bahwa dalam proses 
pewarisan atau pemerolehan suatu keahlian khusus terdapat kegiatan belajar mengajar. Generasi muda melakukan kegiatan belajar dan generasi tua melakukan kegiatan mengajar. Dengan kata lain generasi tua melakukan transfer ilmu kepada generasi muda terkait keahlian pengobatan alternatif penyakit tulang.

Sebagaimana pendapat Bruner yang dikutip oleh Hidayat (1990), menyatakan bahwa proses belajar terjadi dalam 3 (tiga) episode yakni informasi, transformasi, dan evaluasi. Episode informasi adalah proses penjelasan, penguraian, atau pengarahan mengenai prinsip-prinsip struktur pengetahuan, keterampilan, sikap yang diharapkan setelah peserta didik melaksanakan proses belajar. Adapun transformasi adalah proses peralihan atau pemindahan prinsip-prinsip struktur pengetahuan, keterampilan, dan sikap ke dalam diri peserta didik pada saat pelaksanaan proses belajar. Sementara itu, evaluasi adalah taraf penilaian untuk mengukur pencapaian peserta didik terhadap struktur pengetahuan, keterampilan dan sikap setelah peserta didik melaksanakan proses pembelajaran atau setelah guru mentranformasikan ilmu pengetahuan.

Berkaitan dengan pengobatan alternatif penyakit tulang, proses belajar dilakukan oleh dua pihak yaitu terapis dan asistennya. Asisten-asisten terapis sebelum mereka menjadi asisten tentu saja diberikan pengetahuan awal tentang prinsin-prinsip pengobatan penyakit tulang, apa itu penyakit tulang, apa saja faktor penyebabnya, apa saya yang harus diperhatikan dalam proses pengobatan, apa saja obat-obatan yang digunakan, apa saja perlengkapan yang dibutuhkan, berapa lama proses penyembuhan. Hal-hal tersebut dijelaskan dan diuraikan oleh terapis kepada para calon asistennya. Proses belajar tahap awal inilah yang disebut episode informasi.

Selanjutnya, ketika para calon asisten itu sudah dapat menjelaskan kembali dan memahami hal-hal yang disampaikan oleh terapis berkaitan dengan pengobatan alternatif penyakit tulang, maka disitulah proses transformasi terjadi. Para calon asisten telah menyerap ilmu yang disampaikan oleh terapis dan mampu menerapkan atau mempraktikkannya kepada seorang pasien.

Proses transformasi dianggap telah berhasil dilakukan jika para calon asisten tersebut telah berhasil menerapkan bagaimana cara mengobati pasien penyakit tulang mulai dari tahap awal yaitu observasi, kemudian pasien diperiksa fisiknya, termasuk riwayat penyakit terdahulu, keluhan-keluhan yang dialami, kemudian berlanjut pada tahap pengobatan seperti pijat dan reposisi tulang.

Kemudian dilanjutkan ke tahap perawatan yaitu pemeriksaan secara berkala dan pemberian obat tradisional yang berasal dari tumbuh-tumbuhan (obat herbal). Proses tersebut selalu didampingi oleh terapis agar ketika terjadi kesalahan dapat langsung dikoreksi. Proses mengoreksi kesalahan yang dilakukan terapis kepada calon asisten itulah yang dinamakan episode evaluasi. Hal tersebut menunjukkan bahwa tiga episode yang dilakukan dalam proses belajar terjadi secara simultan. Artinya, proses belajar tersebut dilakukan secara bersamaan, tidak menunggu salah satu tahap selesai lebih dahulu melainkan jika ada kesalahan dalam pengobatan tahap pertama misalnya, maka terapis langsung mengoreksi atau mengevaluasi kesalahan tersebut sampai calon asisten betul-betul terampil melakukan pengobatan tahap awal baru kemudian dilanjutkan ke tahap selanjutnya.

\section{PENUTUP}

Berdasarkan uraian di atas terdapat dua simpulan. Pertama, ternyata jumlah praktik pengobatan penyakit tulang cukup banyak tersebar di beberapa wilayah di Jawa Barat. Kedua, banyaknya jumlah terapis, mengindikasikan jumlah pasien pengguna jasa para terapis pun cukup banyak. Pertimbangan para pasien menggunakan jasa para terpis tradisional 
adalah karena faktor sosial, budaya, ekonomi, psikologis, dan alasan kepraktisan.

Metode pengobatan yang digunakan, selain ada unsur yang bersifat spiritual, selebihnya bersifat logis dan rasional. Mengusap, mengurut, dan mereposisi tulang merupakan metode yang umum digunakan. Digunakan juga minyak atau cairan yang bersumber dari tetumbuhan tertentu yang berkhasiat.

Pengetahuan dan keterampilan yang dimiliki oleh para terapis di samping pada umumnya mewarisi keterampilan yang dimiliki orang tuanya, juga melalui pelatihan dan praktik yang berjangka panjang.

Ada beberapa saran yang diajukan. Pertama, sebaiknya pemerintah setempat menginventarisasi jumlah praktisi pengobatan penyakit tulang yang ada di wilayahnya masing-masing. Kedua, sebaiknya ada kerja sama yang sinergis antara para praktisi terapis penyakit tulang, pemerintah setempat, dan dinas-dinas kesehatan. Ketiga, perlu ada upaya sistematis dalam proses pewarisan kecerdasan atau kearifan tradisional kepada generasi berikutnya.

\section{DAFTAR SUMBER}

\section{Jurnal, Prosiding, Tesis dan Skripsi}

Alfian, Magdalia. "Potensi Kearifan lokal dalam Pembentukan Jati Diri dan Karakter Bangsa" dalam Prosiding the $5^{\text {th }}$ ICSSIS; "Ethnicity and Globalization", di Jogyakarta pada tanggal 13-14 Juni 2013.

Fadhila. "Pembiayaan pada Metode Pengobatan Patah Tulang Tradisional" dalam Jurnal Ilmu Keperawatan, Vol. 3, No. 1 2015. Hlm. 50-58.

Hastuti, Supri. 2006.

Sistem Pengobatan Terapi Ruhani Islam Ruqiyah Syar'iyyah (Ruqyah Da'wiyyah) di Tenabang Raqyah Center (TRC) Jakarta Pusat. Skripsi Sarjana Antropologi Fakultas Ilmu Sosial dan Ilmu Politik Universitas Indomesia. Depok: UI.
Kalangi, Nico S.. "Arti dan Lapangan Penelitian Antropologi Medis" dalam Berita Antropologi, VIII (29) 1976. Hlm. 15.

Kasnodiharjo. "Studi tentang Penularan Penyakit Pes dengan Pendekatan Sosioekologi di Dusun Sulorowo, Perbukitan Tengger Bromo, Kabupaten Pasuruan, Jawa Timur" dalam Media Litbang Kesehatan, Volume XV Nomor 1 Tahun 2005.

Kusmaya, Asep Zery. 2014.

Perkembangan dan Sistem Pewarisan Kesenian Angklung Badud di Cijulang Pangandaran. Yogyakarta: Universitas Negeri Yogyakarta.

Lestari, R. Esti. 2004.

Pengobatan Alternatif dengan Tenaga Metafisika dan Tenaga Dalam; Kajian pada Pengobatan Hikmatul Iman di Bandung Jawa Barat. Skripsi Antropologi Fakultas Ilmu Sosial Ilmu Politik Universitas Indonesia. Depok: UI.

Mangunsudirdjo, Saleh. "Kajian Faktor-Faktor yang Membawa Penderita Patah Tulang ke Dukun Patah" dalam Majalah Kedokteran Diponegoro. Vol. 27, no. 4 tahun 1992. Hlm. 76-84.

Muhastiningsih. 1990.

Tinjauan terhadap Peran Serta Dukun Patah Tulang dalam Program Upaya Kesehatan Tradisional di Desa Cimande, Kecamatan Caringin, Kabupaten Bogor. Skripsi. Kesehatan Masyarakat Universitas Indonesia. Depok: UI.

Notosiswoyo, Mulyono. 1995.

Pengobatan Tradisional Patah Tulang Cimande. Tesis. Magister Antropologi Fakultas Ilmu Sosial Ilmu Politik Universitas Indonesia. UI: Depok.

Nurrani, Lis., Supratman Tabba dan Hendra S. Mokodompit. "Kearifan Lokal dalam Pemanfaatan Tumbuhan Obat oleh Masyarakat di Sekitar Taman Nasional Akatejawe Lolobata, Provinsi Maluku Utara" dalam Jurnal Penelitian Sosial dan Ekonomi Kehutanan, Vol. 12, No. 3, Desember 2015. Hlm. 163-175. 
Rahmadewi, Ida. 2009.

Pengobatan Tradisional Patah Tulang

Guru Singa. Skripsi. Antropologi

Fakultas Ilmu Sosial Ilmu Politik Universitas Indonesia. Depok: UI.

Septiani, Ayu dan Asri Soraya Afsari.

"Regenerasi Pemerolehan Seni Lais di Padepokan Lais Pancawarna Kampung Sayang Desa Cibunar Kecamatan Cibatu Kabupaten Garut”, Kaganga Volume 1 Nomor 1 2018. Hlm. 43-44.

Zakaria, Mumuh M. "Bibliografi Sejarah Kesehatan pada Masa Pemerintahan Hindia Belanda" dalam Jurnal Paramita Vol. 22 No. 2 2012. Hlm. 186-197.

\section{Buku}

Agoes A dan Jacob T. 1992.

Antropologi Kesehatan Indonesia Pengobatan Tradisional Jilid I. Jakarta: EGC.

Anderson, Foster. 1986.

Antropologi Kesehatan. Jakarta: Universitas Indonesia.

Departemen Pendidikan Nasional. 2014.

Kamus Besar Bahasa Indonesia Cetakan kedelapan Belas Edisi IV. Jakarta : Gramedia Pustaka Utama.

Direktorat Jenderal PP dan PL, Departemen Kesehatan Republik Indonesia. 2007. Sejarah Pemberantasan Penyakit di Indonesia. Jakarta: Direktorat Jenderal PP dan PL, Departemen Kesehatan Republik Indonesia.

Handoko, Pujo. 2008.

Pengobatan Alternatif. Jakarta: Gramedia.

Hidayat, Kosadi. 1990. Strategi Belajar Mengajar. Bandung: Tanpa Penerbit.

Kuper, Adam. 1999.

Culture. Cambridge: Harvard University Press.

Samsunjaya, Sagita. 2007.

Mengenal Pengobatan Modern dan Alternatif. Jakarta: Visindo Media Persada.
Spradley, James P. 1997.

Metode Etnografi. Yogyakarta: Tiara Wacana.

Wibowo, Agus dan Gunawan. 2015.

Pendidikan Karakter Berbasis Kearifan Lokal di Sekolah. Yogyakarta: Pustaka Pelajar.

\section{Sumber Lisan/Informan}

Hasbi (55 tahun). Terapis di Bengkel Tulang Mande Ujungberung Bandung. Wawancara 3 Agustus 2018.

Achmat Taupik (50 tahun). Terapis di Bengkel Tulang Aa Cimande, Cipadung

Bandung. Wawancar 8 September 2018.

Tini (45 Tahun). Anggota keluarga terapis di Desa Semplak, Sukabumi. Wawancara 11 September 2018. 